\title{
Immunoglobulin levels in infantile pneumocystosis
}

\author{
ELFRIEDE KOHOUT, CORNELIUS POST, BAHRAM AZADEH, WERNER DUTZ, \\ BASHI BANDARIZADEH, AND DARIUS KADIVAR
}

\begin{abstract}
From the Red Lion and Sun Orphanage and the Department of Pathology and Clinical Pathology, Pahlavi University, Shiraz, Iran
\end{abstract}

SYNOPSIS Two hundred and twelve determinations of $\operatorname{IgA}, \operatorname{IgG}$, and $\operatorname{IgM}$ were performed in 50 infants during an epidemic of interstitial plasma cell pneumonia. Criteria for diagnosis are discussed. The immunoglobulin levels in pneumocystic, non-pneumocystic, and normal American infants are compared. An analysis of the findings in individual cases reveals a time-related immunoglobulin response, which helps to elucidate the pathogenicity of the disease.

Pneumocystis carinii is an unclassified saprophyte of the tracheobronchial tree of many animal species (Delanoë and Delanoë, 1912; Weller, 1955; Jírovec, 1960 ) and is also found as a commensal in the human trachea (Esterly and Warner, 1965; Hamlin, 1968). Intraalveolar clusters of Pneumocystis carinii contain varying numbers of encysted forms with eight merozoites within a capsule, which is highly antigenic (Brzosko, Nowosławski, and Madaliński, 1964), and consists of chitosamin, lipoproteins, and mucopolysaccarides (Bruns, 1955). Human infection with Pneumocystis carinii is always associated with some form of immune deficiency.

The human host response varies greatly with the underlying immune defect. Three basic forms can be distinguished:

(1) Hypoergic, hypoimmune pneumocystosis which occurs in drug or radiation-induced hypoimmune states following transplantation (Rifkind, Starzl, Marchioro, Waddell, Rowlands, and Hill, 1964), after prolonged cortisone therapy (Kossel, 1962), or in cases of inherited immune deficiency (Marshall, Weston, and Bodian, 1964; Robbins, Miller, Arean, and Pearson, 1965). This form of pneumocystosis is characterized by the absence of interstitial plasma cell infiltration of the alveolar septa, immune response to the organism, and consequently negative serology. Experimental pneumocystosis is a complete model of hypoergic, hypoimmune pneumocystosis (Weller, 1955; Linhartová, 1958; Sheldon, 1959).

2 Massive, panlobar interstitial plasma cell pneumonia of infants, which was first observed in nursery and orphanage epidemics in Europe after World War II, occurs only in the 2-6-month age Received for publication 29 June 1971. group and is often fatal due to alveolar capillary block caused by the massive interstitial plasma cell infiltrate in the alveolar septa (Dvořák and Jírovec, 1953; Jírovec and Vanek, 1954; Gajdusek, 1957; Koop, 1964).

3 Focal subclinical interstitial plasma cell pneumonia of infants, which is an abortive form of interstitial plasma cell pneumonia, occurs under the same conditions but is recognized only as a chance finding at necropsy or due to the positive complement-fixation reaction after the disease is terminated (Hamperl, 1957; Woodward and Sheldon, 1961).

An epidemic in a Shiraz orphanage with a high mortality rate (Table I) was studied between 1962 and 1968 (Post, Dutz, and Nasarian, 1964; Thomas, Dutz, and Khodadad, 1966; Dutz, 1970).

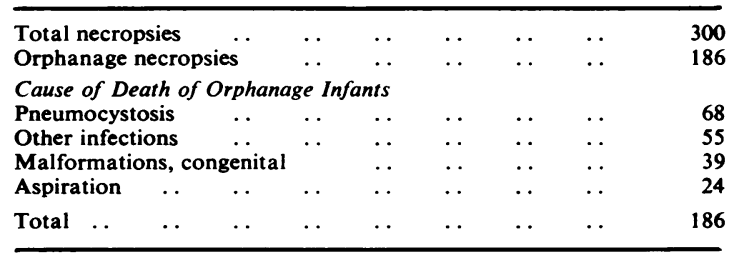

Table I Infants necropsied at Pahlavi University, Shiraz, 1961-1967

All the children suffered from severe diarrhoea, marasmus, and many intercurrent infections. The bowel mucosa showed severe atrophy and tropical sprue (Creamer, Dutz, and Post, 1970). To elucidate the conditions leading to interstitial plasma cell and focal subclinical pneumonia the qualitative and quantitative levels of $\operatorname{IgA}$, IgM, and IgG were studied. 


\section{Materials and Methods}

Sixty-five infants admitted to the orphanage shortly after birth in the period from January 1966 to January 1968 were studied. Complete clinical charting was introduced. Special attention was paid to respiratory signs and symptoms. The following tests were performed once monthly, more often if clinically indicated: chest radiographs; complementfixation test with the Barta (Bárta, Dvořáček, and Kadlec, 1955) and later the Vivell (Vivell, 1955) method; tracheal aspiration with direct laryngoscopy and bronchial catheterization, sublimate fixation of smears and Giemsa staining. The microscopic examination and interpretation of the aspirates was performed by one pathologist only. Serum was obtained from each infant by intravenous puncture once a month for immunoglobulin determination, more frequently if indicated by symptoms as for instance during a respiratory crisis with cyanosis. Serum protein levels were determined by the microbiuret reaction, simultaneous analysis by paper electrophoresis, and cellulose-acetate microelectrophoresis with the Beckman Analytrol system. Immunoelectrophoresis in agar gel plates against antihuman IgA, IgM, and IgG was performed separately. Quantitative levels of IgA, IgM, and IgG were determined with Highland immunoplates and compared with the Highland standard.

Additionally immunofluorescent studies were performed on several selected lungs to determine the levels of IgA and IgM in the alveoli. The lungs of two infants with diffuse interstitial plasma cell pneumonia and marked Pneumocystis carinii infestation were removed at necropsy within two hours after death and immediately frozen in a deep freeze chest below minus $\mathbf{4 0}$ degrees Centigrade. They were kept frozen for four and six months respectively. The control lungs were stored and frozen under identical conditions in the same freezer. The following controls were used: the lung of a 3-month-old infant without pulmonary disease, stored for three months; the lung of a 6-month-old infant without pulmonary disease stored for five months; the lung of an infant aged 3 months dying of bronchopneumonia, stored for six months; the lung of a 6-month-old infant with thymic alymphoplasia of Bruton type stored for one month; and the lung of a normal adult stored for five months. Eight cryostat sections were prepared from different areas of each lung.

Rabbit antihuman IgA and IgM (Burroughs Wellcome) was diluted in isotonic phosphate buffer 1:20 and 1:40 immediately before use. Horse antirabbit immunoglobulin conjugated with fluoresceinisothiocyanate was diluted $1: 5$ in isotonic phosphate buffer. The frozen sections were washed by dipping into isotonic phosphate buffer three times, air dried in a $37^{\circ} \mathrm{C}$ incubator, covered with acetone for 10 minutes, dried again as before and then covered with the rabbit antihuman IgA and IgM for 20 hours in a moist chamber at $4^{\circ} \mathrm{C}$. The slides were then thoroughly washed with isotonic phosphate buffer, dried and exposed to fluorescent horse antirabbit immunoglobulin and incubated in a moist chamber at room temperature for one hour. The sections were then thoroughly rinsed again in isotonic os phosphate buffer, mounted in pure glycerin diluted $\vec{\circ}$ with buffered saline, and examined under the fluorescent phase contrast microscope (Coons and Kaplan, 1950; Coons, Leduc, and Kaplan, 1961).

The results of the immunoglobulin fluorescent staining of two lungs with interstitial plasma cell pneumonia and several control lungs stored under the same conditions show a marked predominance of IgM in the alveolar walls and coating the alveoli with complete absence of IgA (Table II).

\begin{tabular}{|c|c|c|}
\hline & \multicolumn{2}{|c|}{ Alveolar Fluorescence } \\
\hline & $\operatorname{Ig} A$ & $\operatorname{Ig} M$ \\
\hline Pneumocystic lung & - & $++t$ \\
\hline Infant 3 months & + & - \\
\hline Infant 6 months & + & - \\
\hline Infant with bronchopneumonia & + & + \\
\hline Infant with Bruton's disease & - & + \\
\hline Normal adult lung & $+t$ & - \\
\hline
\end{tabular}

Table II Presence of alveolar fluorescence

\section{Discussion}

Several series of quantitative immunoglobulin determinations in nursery epidemics of pneumocystosis are reported (Koltay and Illyés, 1966; Pozzuoli and Corda, 1966; Pozzuoli, Parma, and Costanzi, 1966), in which no specific time relation to the radiological lesion was established and stringent diagnostic criteria beyond those of clinical and radiological suspicion were not applied. The results conform essentially to our unsorted data, not distinguishing between interstitial and focal plasma cell pneumonia.

The clinical picture of severe interstitial plasma cell pneumonia is characterized by a rapidly developing cyanosis and tachypnoea with air hunger, frequently leading to death within 24 hours after onset. The pathological substrate is a massive interstitial plasma cell infiltration of the lung. Kouvalainen, Hjelt, and Wasz-Höckert (1964) described a case with marked elevation of beta $2 \mathrm{M}$ (IgM) globulin during a lethal respiratory crisis. Studies with fluorescent IgM showed specific coating 


\begin{tabular}{|c|c|c|c|c|c|c|c|c|c|c|c|}
\hline \multirow[t]{2}{*}{ Group } & \multirow{2}{*}{$\begin{array}{l}\text { No. of } \\
\text { Cases }\end{array}$} & \multicolumn{4}{|c|}{ Clinical Symptoms } & \multicolumn{3}{|l|}{ Laboratory } & \multirow[t]{2}{*}{ Deaths } & \multirow[t]{2}{*}{ Necropsy Diagnosis } & \multirow[t]{2}{*}{ Result } \\
\hline & & Coug & h Retraction & Tachypnoea & Cyanosis & Radiograph & Aspirate & Serology & & & \\
\hline I & 6 & 6 & 6 & 6 & 6 & + & + & & 6 & $\begin{array}{l}\text { Diffuse interstitial plasma } \\
\text { cell pneumonia }\end{array}$ & + \\
\hline II & 14 & 14 & 14 & 14 & 2 & + & + & + & 1 & $\begin{array}{l}\text { Late death, unspecific } \\
\text { infiltrate }\end{array}$ & $\div$ \\
\hline III & 8 & 8 & 6 & 6 & 2 & + & - & + & 1 & $\begin{array}{l}\text { Late death, unspecific } \\
\text { infiltrate }\end{array}$ & + \\
\hline IV & 5 & 5 & 3 & 3 & 0 & - & - & + & 1 & $\begin{array}{l}\text { Late death, unspecific } \\
\text { interstitial infiltrate }\end{array}$ & + \\
\hline $\mathbf{V}$ & 7 & 7 & 7 & 7 & 5 & + & + & $?$ & 0 & & $\begin{array}{l}\text { Probable } \\
+\end{array}$ \\
\hline $\begin{array}{l}\text { VI } \\
\text { VII }\end{array}$ & $\begin{array}{r}6 \\
19\end{array}$ & $\begin{array}{r}6 \\
19\end{array}$ & $\begin{array}{r}6 \\
16\end{array}$ & $\begin{array}{r}6 \\
17\end{array}$ & $\begin{array}{l}2 \\
2\end{array}$ & $+(12)$ & + & $\overline{-}$ & $\begin{array}{l}\mathbf{0} \\
\mathbf{0}\end{array}$ & & $\overline{-}$ \\
\hline Total & 65 & 65 & 58 & 59 & 19 & & & & 9 & & $\begin{array}{l}33 \text { confirmed } \\
\text { diagnoses }\end{array}$ \\
\hline
\end{tabular}

Table III Sixty-five cases of clinically suspected pneumocystosis January 1966 to July 1968

of the pneumocystis capsules (Brzosko, Madaliński, and Nowosławski, 1967).

Focal pneumocystosis cannot be differentiated from other pulmonary infiltrations on clinical or radiological grounds. Only a positive serological test, which occurs three to six weeks after the onset of pneumocystosis, is of diagnostic value (Table III). Necropsy reveals only focal plasma cell infiltrates around small clumpings of the organisms.

Between birth and the fourth or fifth month of life, the infant's body responds to antigenic challenges, principally with IgM antibody production, later on with IgG. Unless a clear distinction between focaland

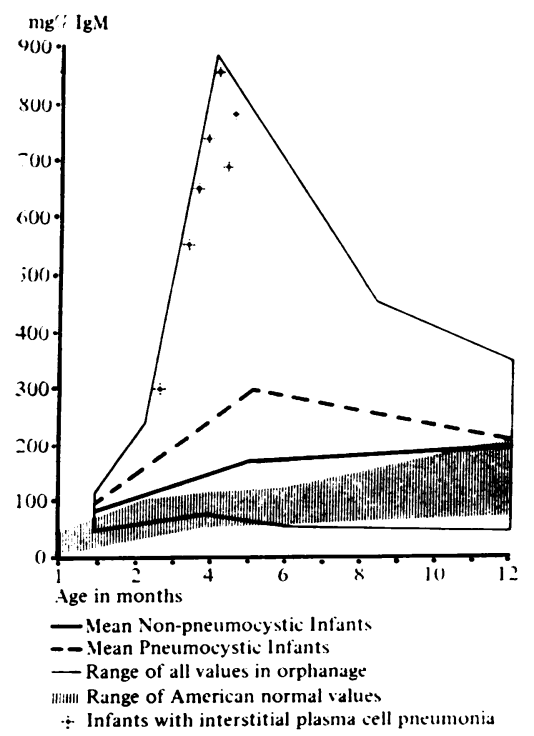

Fig. 1 IgM levels in orphanage. interstitial plasma cell pneumonias and other infections is made, an analysis of immunoglobulin levels will lead to non-specific results. In our series a general elevation of all immunoglobulins can be detected, which is not significantly different in pneumocystic and non-pneumocystic infants (Fig. 1). There is a noticeable elevation of all immunoglobulin levels as compared with normal American infants of the same age group due to the frequent and various infections amongst the orphanage infants. The wide range with several cases with extremely low levels may be related to malnutrition and protein loss (Creamer et al, 1970; Dutz, Sadri, Kohout, Post, and Bandarizadeh, 1970).

Infants with severe respiratory symptoms, diffuse rapid clouding of the $x$-ray picture, and all pathognomonic changes of acute interstitial plasma cell pneumonia as well as those showing massive disease at necropsy are found exclusively amongst the highest values of the IgM range (Figs. 2 and 4). Three cases showed elevations of more than 2 standard devia-

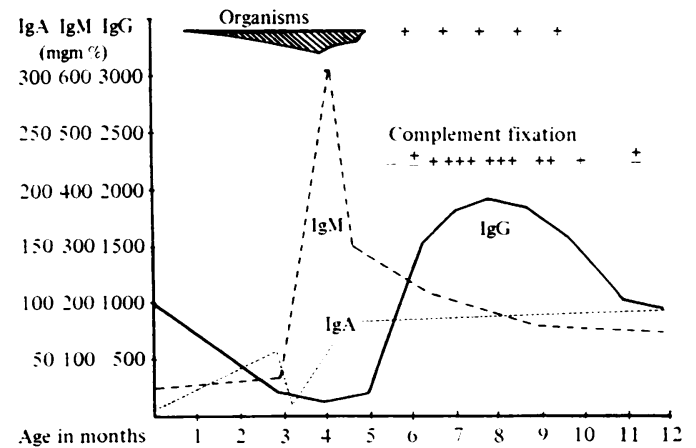

Fig. 2 Summary of immune response in case of Pneumocystis carinii infection with plasma cell pneumonia. 
tions. The elevation of the IgM levels is directly related to the amount of plasma cell infiltrate as judged by those cases necropsied as well as by observation of the radiological density of the infiltrate in cases which later were proven serologically. This is most important, since we know of no other disease in this age group which would produce a similar intense plasma cell response. The peak values of IgM can only be detected during a short and limited time period (Figs. 2 and 4). The peak levels are reached two to three days after the crisis followed by a rapid fall. This explains the paucity of well studied cases of interstitial plasma cell pneumonia, since it is difficult to obtain sera at the right moment. Our studies with fluorescent IgM confirmed the findings of Brzosko et al (1967) and revealed a very marked increase in intraalveolar and plasmacellular IgM in cases of acute interstitial plasma cell pneumonia.

IgG levels show on superficial examination similar patterns in interstitial and focal plasma cell pneumonia and nonpneumocystic infants (Fig. 3). Infants with massive interstitial plasma cell pneumonia are, however, found at the lowest level of the range with IgG values of less than $200 \mathrm{mg} \%$. This corresponds to the experiences in experimental pneumocystosis as well as adult pneumocystosis, where hypoergic, hypoimmune pneumocystosis develops in severely immune-depressed individuals. The low infantile IgG levels are related to prematurity, atrophy of the bowel mucosa, and marasmus. The complement-fixation test remains negative during this period of high IgM and low IgG levels.

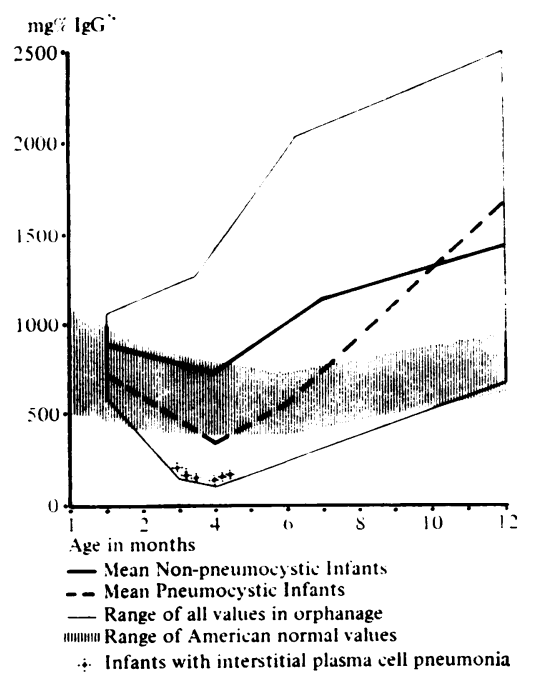

Fig. 3 IgG levels in orphanage.
The survivors respond by the fifth to sixth month of life with an increase in IgG levels indistinguishable from the reaction to infections other than pneumocystosis, except by the concomitant positive complement-fixation test. The titre of the complementfixation test parallels the quantitative levels of IgG rather than IgM and the complement-fixing antibodies are therefore probably of the IgG type. Tests are occasionally positive in newborns with transferred IgG from the mother, rapidly turning negative. Positive reactions are not detected during the second to fifth month of life (Post, Fakouhi, Dutz, Bandarizeh, and Kohout, 1971) which means that antibody against Pneumocystis carinii is negligible. Serological reactions for Pneumocystis carinii are negative in all cases of hypoergic hypoimmune pneumocystosis (Goetz, 1966; Robbins, 1968; Fischer, Becker, Joist, and Tismer, 1969) since the naturally occurring IgG response seen in infants is artificially prevented for 윽 therapeutic reasons or does not occur due to con- genital immunoglobulin deficiency syndromes. Re- T currences of pneumocystosis have been observed in cases of hypoergic hypoimmune pneumocystosis but never in interstitial or focal plasma cell pneumonia (Frenkel, 1968).

The determination of serum IgA levels in orphars $N$ age children from Shiraz showed on average a increase over the normal American levels (Fig. $4 \bar{\phi}$. Three of our cases showed a marked sudden drop in IgA preceding a respiratory crisis by two to three days. None of the other IgA determinations in our series was performed during this unpredictable period of time shortly before the massive spread of pneumocystis through the alveoli of the lung. Determinations of fluorescent IgA on two lungs with acute interstitial plasma cell pneumonia showed complete absence of alveolar IgA.

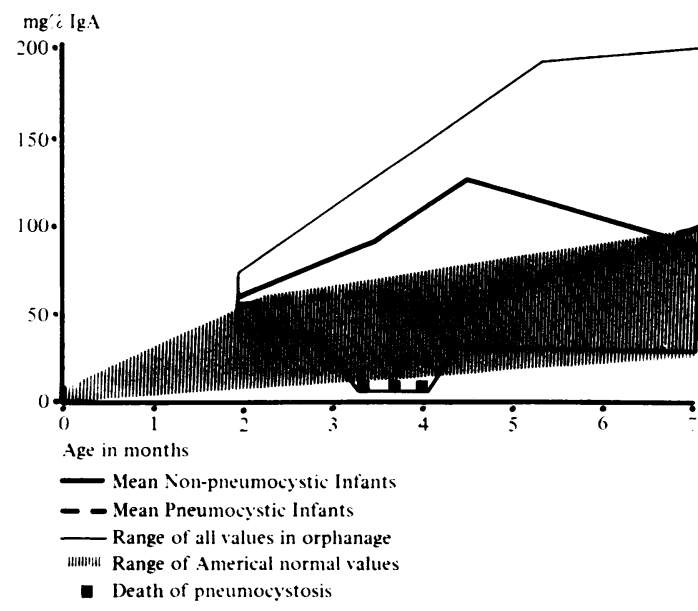

Fig. 4 Ig A levels in orphanage. 
Cases of adult or infantile hypoergic hypoimmune pneumocystosis show either low or normal serum IgA levels (Robbins, 1968). They are frequently associated with a complete absence of the alveolar lining and fibrin membrane formation or severe abnormalities of the lining cells with giant cell formation and alveolar cell degeneration as in inclusion body virus disease and after busulphane therapy. One of the authors (W. Dutz) examined the lungs of 36 cases of hypoergic hypoimmune pneumocystosis in the USA related to various immunosuppressive drug regimes or congenital immune deficiencies. Serum $\operatorname{IgA}$ levels were invariably low when the alveolar lining was intact. In cases associated with alveolar cell degeneration the serum IgA levels were either normal or low.

IgA is produced by plasma cells, coupled and secreted by epithelial cells to provide surface immune protection (South, Warwick, Wollheim, and Good, 1967; Tomasi and Czewinski, 1968; Martin, 1969; Heremans, 1969). IgA is frequently absent in severe sprue (Heremans, 1969). The invariable association of severe intestinal atrophy with a sprue-like histological pattern (Creamer et al, 1970) appears to be of added interest. Although all our findings suggest and point to an absence of alveolar $\operatorname{IgA}$ as a prerequisite to the proliferation of this surface spreading parasite, definite clarification of the problem will only be derived from bronchial IgA determinations in affected patients.

We would like to propose from our findings the following hypothesis of the development of interstitial plasma cell pneumonia which is summarized in Figure 4. Complement-fixing antipneumocystic antibodies are transferred to the infant with maternal IgG. The levels of these passively transferred immunoglobulins drop to less than $200 \mathrm{mg} \%$ by the third or fourth month after birth, due to natural degradation. This drop is more pronounced in premature infants in whom the interval between birth and immuno-competence is prolonged and aggravated by intestinal infections with sprue-like atrophy of the mucosa and marasmus. The low IgG is the precondition for the intraalveolar proliferation of Pneumocystis carinii. Normally IgA prevents surface infection. If serum IgA is absent, alveolar IgA secretion ceases, or the alveolar cells are severely damaged, sudden, explosive, logarithmic proliferation of pneumocystis occurs. The highly antigenic capsules elicit a massive interstitial plasma cell response and IgM antibody formation. The infants die of an alveolar capillary block or survive, the organisms disappearing from the alveoli within a week. The plasma cell infiltrate persists, gradually diminishing in amount over several months and is responsible for the slow resolution of the radiological opacities. The active formation of IgG antibodies starts at the fifth, and reaches its peak at the ninth month of life. Complement-fixing antibodies show their highest titres during this period.

This research was supported by NIH grant A1 06404-01/02 as well as funds from CENTO and Pahlavi research grants. We are indebted to Emeritus Professor N. Martin, London, and Burroughs Wellcome for the fluorescent IgA and IgM as well as for instruction in the methodology.

We also would like to thank the technicians of the Clinical Pathology Department for their help.

\section{References}

Bárta, K., Dvořảek, C., and Kadlec, A. (1955). Komplementbindungs-Reaktion bei Pneumocysten Pneumonien. Schweiz. Z. allg. Path., 18, 33-32.

Brzosko, W. J., Madaliński, K., and Nowoslawski, A. (1967). Immunofluorescent and immunoelectrophoretic reactions in children with pneumonia due to Pneumocystis carinii. (Polish). Med. Dosw. Mikrobiol., 19, 373-380.

Brzosko, W. J., Nowosławski, A., and Madaliński, K. (1964). Identification of immune complexes in lungs from Pneumocystis carinii pneumonia cases in infants. Bull. Acad. pol. Sci., Cl, 6, 12, 137-142.

Bruns, G. (1955). Die Membranhülle der Pneumocystis carinii. Naturwissenschaften, 42, 610.

Coons, A. H., and Kaplan, M. H. (1950). Localization of antigen in tissue cells. II. Improvements in a method for the detection of antigen by means of fluorescent antibody. J. exp. Med., 91, 1-13.

Coons, A. H., Leduc, E. H., and Kaplan, M. H. (1961). Localization of antigen in tissuecells. VI. The fate of injected foreign proteins in the mouse. J. exp. Med., 93, 173-188.

Creamer, B., Dutz, W., and Post, C. (1970). The small intestinal lesion of chronic diarrhoea and marasmus in Iran. Lancet, $1,18-20$.

Delancë, P., and Delanoë, M. (1912). Sur les rapports des kystes de carini du poumon des rats avec le Trypanosoma lewisi, C.R. Acad. Sci. (Paris), 115, 658-660.

Dutz, W. (1970). Pneumocystis carinii pneumonia. Path. Ann., 1970, pp. 309-341.

Dutz, W., Sadri, S., Kohout, E., Post, C., and Bandarizadeh, B. (1970). Bowel mucosal patterns and immunoglobulins in 100 infants from birth to one year of age. Pahlavi med, J., 1, 234-243.

Dvořák, J., and Jírovec, O. (1953). Diagnostik und Therapie der durch Pneumocystis carinii verursachten parasitären atypischen Pneumonien bei Säuglingen. Acta paediat. (Uppsala), 42, 232-254.

Esterly, J. A., and Warner, N. E. (1965). Pneumocystis carinii pneumonia. Twelve cases in patients with neoplastic lymphoreticular disease. Alch. Path., 80, 433-441.

Fischer, R., Becker, H. D., Joist, J. H., and Tismer, R. (1969). Pneumocystis Carinii Pneumonie beim Erwachsenen. Dtsch. med. Wschr., 94, 2135-2140.

Frenkel, J. K., (1968). Experimental model of pneumocystosis in rats: pathogenesis and therapy (Abstr.). In 8 th International Congress of Tropical Medicine and Malaria, Tehran, pp. 928-929.

Fulginiti, V. A., Sieber, O.F., Jr., Claman, H.N., and Merill, D.(1966). Serum immunoglobulin measurement during the first year of life and in immunoglobulin deficiency states. J. Pediat., 68, 725-730.

Gajdusek, D. C. (1957). Pneumocystis carinii: etiologic agent of interstitial plasma cell pneumonia of premature and young infants. Pediatrics, 19, 543-565.

Goetz, O. (1966). Serologische Untersuchungen bei einem sogenannten Altersfall von Pneumocystis carinii-Pneumonie. $Z$. Kinderheilk., 95, 1-10.

Hamlin, W. B. (1968). Pneumocystis carinii. J. Amer. med. Ass., 204, 173-174.

Hamperl, H. (1957). Uber heilende und abortive Pneumocystis Pneumonie. Virchows Arch. path. Anat., 330, 325-336.

Heremans, J. F. (1969). Die biologische Bedeutung desexokrinen IgA Immunoglobulins. Behring Mitteilungen, 49, 28-53. 
Jirovec, O., and Vanek, J. (1954). Zur Morphologie der Pneumocystis carinii und zur Pathogenese der Pneumocystis Pneumonie. $\mathrm{Zbl}$. allg. Path. path. Anat., 92, 424-437.

Jirovec, O. (1960). Toxoplasmose und Pneumozystose als Anthropozoonose. Dtsch. Gesundh.-wes., 15, 2383-2387.

Koltay, M., and Illyes, M. (1966). A study of immuneglobulins in the blood serum of infants with interstitial plasmacellular pneumonia. Acta paediat. (Uppsala), 55, 489-496.

Koop, M. J. (1964). Pneumocystis pneumonie. Thesis, Amsterdam.

Kossel, A. (1962). Interstitielle plasmazelluläre Pneumonie beim älteren Kind als Folge langdauernder Corticosteroidbehandlung. Dtsch. med. Wschr., 87, 1133-1139.

Kouvalainen, K., Hjelt, L., and Wasz-Höckert, O. (1964). Marked elevation of beta $2 \mathrm{M}$ globulin in a patient with interstitia plasmacell pneumonia. Acta paediat. (Uppsala), 53, 465-469.

Linhartová, A. (1958). Herdförmige, klinisch latente Pneumozystis Pneumonie. Zbl. allg. Path. path. Anat., 98, 183-188.

Marshall, W. C., Weston, H. J., and Bodian, M. (1964). Pneumocystis carinii pneumonia and congenital hypogammaglobulinaemia. Arch. Dis. Childh., 39, 18-25.

Martin, H. N. (1969). Molecular defence. In Trends in Clinical Pathology, pp. 203-219. Published for the Association of Clinical Pathologists by the British Medical Association, London.

Post, C., Dutz, W., and Nasarian, I. (1964). Endemic pneumocystis carinii pneumonia in South Iran. Arch. Dis. Childh., 39, 35-40.

Post, C., Fakouhi, T., Dutz, W., Bandarizadeh, B., and Kohout, E. (1971). Prophylaxis of epidemic infantile pneumocystosis with a 20:1 sufadoxine + Pyrimethamine combination. Curr. ther. Res., 13, 273-279.

Pozzuoli, R., and Corda, G. (1966). Caratterizzazione della immuno-globuline nella pneumocistosi infantile. Clin. Pediat. (Bologna), 48, 541-554.

Pozzuoli, R., Parma, A., and Costanzi, G. (1966). Aspetti isto-immunologici della polmomite interstiziale plasmacellulare da pneumocystis carinii. Minerva. Med., 57, 4344-4348.
Rifkind, D., Starzl, T. E., Marchioro, T., Waddell, W. R., Rowlands, D. T., Jr., and Hill, R. B., Jr. (1964). Transplantation pneumonia. J. Amer. med. Ass., 189, 808-812.

Robbins, J. B. (1968). Immunological and clinicopathological aspects of pneumocystis carinii pneumonitis. In Immunological Deficiency Diseases in Man (Birth Defects Original Article Series, vol. IV, no. 1) edited by D. Bergsma and R. A. Good, pp. 219-244. National Foundation-March of Dimes, New York.

Robbins, J. B., Miller, R. H., Arean, V. M., and Pearson, H. A. (1965). Successful treatment of pneumocystis carinii pneumonitis in a patient with congenital hypogammaglobulinemia. New. Engl.J. Med., 272, 708-713.

Sheldon, W. H. (1959). Experimental pulmonary pneumocystis carinii infection in rabbits. J. exp. Med., 110, 147-160.

South, M. A., Warwick, W. J., Wollheim, F. A., and Good, R. A. (1967). IgA levels in the serum and saliva of pediatric patients -evidence for a local immunological system. J. Pediat, 71, 645-653.

Thomas, S. F., Dutz, W., and Khodadad, E. J. (1966). Pneumocystis carinii pneumonia. (Plasmacell pneumonia). Roentgenographic pathological and clinical correlation. Amer. J. Roentgenol., 98, 318-322.

Tomasi, T. B., Jr., and Czewinski, D. S. (i 968). The secretory IgA system. In Immunologic Deficiency Diseases in Man, edited by D. Bergsma (Birth Defects; Original article series, vol. 4, no. 1), pp. 270-282. National Foundation, New York.

Vivell, O. (1955). Ein neues stabiles Antigen für die Serodianose der interstitiellen plasmazellulären Pneumonie junger Säuglinge und Frühgeburten. Dtsch. med. Wschr., 80, 1357.

Weller, R. (1955). Zur Erzeugung von Pneumocystosen im Tierversuch Z. Kinderheilk., 76, 366-378.

Woodward, S. C., and Sheldon, W. H. (1961). Subclinical pneumocystis carinii pneumonitis in adults. Bull. Johns Hopk. Hosp., 109, 148-159. 